\title{
Mating system of Datura inoxia: Association between selfing rates and herkogamy within populations
}

\author{
Vania Jiménez-Lobato ${ }^{1,2}$, Juan Núñez-Farfán ${ }^{\text {Corresp. } 2}$ \\ 1 Facultad de Desarrollo Sustentable, Universidad Nacional Autónoma de México, Técpan de Galena, Guerrero, Mexico \\ 2 Laboratorio de Genética Ecológica y Evolución, Departamento de Ecología Evolutiva, Instituto de Ecología, Universidad Nacional Autónoma de México, \\ Ciudad de México, Distrito Federal, Mexico \\ Corresponding Author: Juan Núñez-Farfán \\ Email address: farfan@unam.mx
}

Plant mating system determines, to a great extent, the demographic and genetic properties of populations, hence their potential for adaptive evolution. Variation in plant mating system has been documented between phylogenetically related species as well between populations of a species. A common evolutionary transition, from outcrossing to selfing, is likely to occur under environmental spatial variation in the service of pollinators. Here, we studied two phenotypically (in floral traits) and genetically (in neutral molecular markers) differentiated populations of the annual, insect-pollinated, plant Datura inoxia in Mexico, that differ in the service of pollinators (Mapimí and Cañada Moreno). First, we determined the populations' parameters of phenotypic in herkogamy, outcrossing and selfing rates with microsatellite loci, and assessed between generation (adults and seedlings) inbreeding, and inbreeding depression. Second, we compared the relationships between parameters in each population. Results point strong differences between populations: plants in Mapimí have, on average, approach herkogamy, higher outcrossing rate $\left(t_{m}=0.68\right)$, lower primary selfing rate $(r=0.35)$, and lower inbreeding at equilibrium $\left(F_{\mathrm{e}}=0.24\right)$ and higher inbreeding depression $(\delta=0.25)$, than the populations of Cañada. Outcrossing seems to be favored in Mapimí while selfing in Cañada. The relationship between $r$ and $F_{e}$ were negatively associated with herkogamy in Mapimí; here, progenies derived from plants with no herkogamy or reverse herkogamy had higher selfing rate and inbreeding coefficient than plants with approach herkogamy. The difference $F_{e}-F$ is positively related to primary selfing rate $(r)$ only in Cañada Moreno which suggests inbreeding depression in selfing individuals and then genetic purging. In conclusion, mating system evolution may occur differentially among maternal lineages within populations of Datura inoxia, in which approach herkogamy favors higher outcrossing rates and low levels of inbreeding and inbreeding depression, while no herkogamy or reverse herkogamy lead to the evolution of the "selfing syndrome" following the purge of 
deleterious alleles despite high inbreeding among individuals. 


\section{Introduction}

2 Plant mating systems affect the demographic dynamics and genetic structure of plant populations,

3 and thus their adaptive potential (Charlesworth \& Charlesworth, 1979; Eckert et al., 2009).

4 Mating systems often vary widely among populations of self-compatible species, from

5 predominant or complete selfing to complete outcrossing. Intermediate (or mixed) mating

6 systems, i.e., those that combine selfing and outcrossing strategies, are also common in nature

7 (Stebbins, 1957; Goodwillie, Kalisz \& Eckert, 2005; Barrett, 2010).

8 The transition from outcrossing to selfing is one of the most frequent evolutionary shifts

9 in flowering plants (Stebbins, 1957; Barrett, 2010; Sicard \& Lenhard, 2011). Evidence of this

10 phenomenon comes from phylogenetic studies (Goodwillie, 1999; Foxe et al., 2009),

11 investigating differences within and among species, and at different geographic scales (Duncan \&

12 Rausher, 2013; Wright, Kalisz \& Slotte, 2013).

13 Two main scenarios are thought to favor the evolution of selfing. One is the transmission

14 advantage of selfers relative to outcrossers (3:2 gametes), which would promote the spread of

15 selfing modifiers in a population unless prevented by natural selection (Fisher, 1941). The second

16 scenario considers that under ecological conditions that are unfavorable for cross-pollination (i.e.,

17 rarity or absence of potential mates and/or pollen vectors), natural selection would favor

18 reproductive assurance through selfing (Baker, 1955; Stebbins, 1957; Schoen \& Lloyd, 1992;

19 Schoen, Morgan \& Bataillon, 1996). Despite the potential transmission and reproductive

20 advantages, selfing as a mating system may also restrict gene flow within and among

21 populations. Consequently, selfing might increase levels of inbreeding and homozygosity, and

22 ultimately the likelihood of inbreeding depression $(\delta)$ in populations (Charlesworth \&

23 Charlesworth, 1987; Charlesworth \& Wright, 2001; Takebayashi \& Morrell, 2001). Therefore,

24 the inbreeding coefficient $(F)$ is expected to correlate with historical level of selfing in a 
25 population. In the long term, however, theoretical models and empirical evidence suggest that

26 increasing levels of inbreeding promote selection against inbred individuals by purging

27 populations of lethal or deleterious alleles, thus reducing genetic load (Husband \& Schemske,

28 1996; Takebayashi \& Delph, 2000; Crnokrak \& Barrett, 2002; Morran, Parmenter \& Phillips,

29 2009). Hence, populations with a long history of inbreeding are expected to have lower levels of

30 inbreeding depression (Yahara, 1992)

31 Herkogamy, the spatial segregation of sex organs within the flower, is considered a main

32 floral trait affecting selfing rates (Webb \& Lloyd, 1986). In hermaphroditic flowers, the

likelihood of selfing is reduced when the stigma surpasses the length of the anthers (i.e., approach

34 herkogamy), because flower stigmas are prevented from receiving self-pollen. In presence of

pollinators, this also provides the opportunity for outcross pollen to first reach the stigmas. In

contrast, when the anthers and stigmas are placed at the same level (i.e., no - herkogamy) or the

stigmas are below the anthers (i.e., reverse herkogamy), selfing is likely to occur, with

(facilitated) or without (autonomous) pollinators (Lloyd, 1992). At the population level, the

relationship between herkogamy and selfing/outcrossing rates may be an indicator of the

historical reliability of pollination (Opedal, 2018). Within-population, this relationship may also

be explained by other causal mechanisms. For instance, stigma clogging may increase

competition between self- and cross-pollen in non-herkogamous flowers, favoring higher

outcrossing rates in herkogamous flowers, or just because self-pollen deposition during pollinator

visits creates a 'shield' against interference from heterospecific pollen (Opedal, 2018). Also, a

positive correlation between approach herkogamy and floral traits related to pollinator attraction,

contributes to the maintenance of the relationship between herkogamous flowers and an 
50 and thus be favored by selection, but it should also positively correlate with selfing rate.

51 Contrary, natural selection might favor/maintain approach herkogamy thus increasing outcrossing

52 rate (Motten \& Stone, 2000; Elle \& Hare, 2002; Herlihy \& Eckert, 2007). Herkogamy is a complex trait determined by genetic and ecological factors (Ashman \&

54 Majetic, 2006; Opedal et al., 2017). Within populations, standing genetic variation in herkogamy

55 would depend on the history of selection of herkogamy on individual lineages, and its adaptive

56 value could depend upon selection pressures exerted by pollinators - particularly when the

57 abundance of pollinators fluctuates in time- or to other selective factors. When associations among selfing rate $(s)$, inbreeding coefficient $(F)$ and herkogamy are maintained over time,

59 within-population covariance among these variables may be established at the lineage level. Significant associations between high outcrossing rate and approach herkogamy have been reported before (Takebayashi, Wolf \& Delph, 2006; de Vos et al., 2018; but see Chen et al., 2009; Brys \& Jacquemyn, 2012; Opedal, Armbruster \& Pélabon, 2015; Toräng et al., 2017). However, few studies have evaluated the association between herkogamy and outcrossing rate within-populations (Epperson \& Clegg, 1987; Moten \& Antonovics, 1992; Carr \& Fenster, 1994; Karron et al., 1997; Brunet \& Eckert 1998; Takebayashi \& Delph, 2000; Elle \& Hare, 2002;

66 Medrano, Herrera \& Barret, 2005; Herlihy \& Eckert, 2007) and even fewer have considered relationships among herkogamy, inbreeding coefficient and mating system. disturbed and/or arid habitats) where pollinator abundance is reduced and/or unpredictable (Friedman \& Rubin, 2015). Under variable pollination service, daily and seasonal fluctuations present different opportunities for cross- or self-fertilization maintaining variation on traits that affect the plants' mating system, such as herkogamy or the inbreeding history of each maternal

73 lineage (Schoen \& Lloyd, 1992; Schoen, Morgan \& Bataillon, 1996; Morgan \& Wilson, 2005;

74 Eckert, Samis \& Dart, 2006; Barrett, 2010; Shirk \& Hamrick, 2014; Pannell, 2015). However, it 
75 is not clear how strong and how frequently the association between mating strategies, herkogamy

76 and inbreeding history of lineages occur within populations in short-lived species. Here, we

77 assessed the within-population mating system dynamics, with replication in two populations of

78 the annual plant Datura inoxia Mill. We focus on the within-population level and less on among-

79 population expectations in order to detect if individuals with more herkogamous flowers show a

80 history of less inbreeding associated to lower levels of selfing. Until now, relative few studies

81 (see review in Opedal, 2018) have assessed these associations within (rather than among)

82 populations.

\section{Materials and Methods}

85 Study species and sampled populations

86 Datura inoxia (Solanaceae) is a summer annual, self-compatible plant that inhabits arid and semi-

87 arid lands in Mexico and Southern USA (i.e., The Chihuahuan desert) (Barclay, 1959;

88 Lockwood, 1973). High daily fluctuation of ambient temperature is a characteristic of these

89 ecosystems. The onset of flowering of D. inoxia is in July and lasts through September, similar to

90 other Datura species (Bronstein et al., 2009). Datura inoxia produces large, funnel-shaped, and

91 nectar producing hermaphroditic flowers that open at dusk and remain receptive for only one

92 night. During the flowering period, individuals can display from a few up to tens of flowers each

93 night. Flower traits related to mating system such as herkogamy and flower size, vary widely

94 within and among populations (Jiménez-Lobato \& Núñez-Farfán, 2012). Further, comparisons

95 between genetic differentiation at neutral loci $\left(F_{S T}\right)$ and phenotypic differentiation $\left(Q_{S T}\right)$ in floral

96 traits suggest adaptive evolution under diverging selection (Jiménez-Lobato \& Núñez-Farfán,

97 2012). Flowers are commonly visited by honeybees, which collect pollen, and hawkmoths 
98 (Manduca sexta, M. quinquemaculata and Hyles lineata) which forage for nectar (Barclay, 1959;

99 Lockwood, 1973; Grant, 1983; McCall et al., 2018; V. Jiménez-Lobato, pers. Obs.).

100 Two populations of $D$. inoxia were selected to assess the relationships between

101 herkogamy, selfing rate, and inbreeding. A previous report (Jiménez-Lobato \& Núñez-Farfán,

102 2012) indicated substantial within-population variation in herkogamy and flower size. The

103 Cañada de Moreno population (CM) is located in the State of Querétaro $\left(21^{\circ} 17^{\prime} 43^{\prime \prime} \mathrm{N} ; 100^{\circ} 31^{\prime}\right.$

104 00" W) in the Mexican Bajío at 1933 m a.s.l. During the flowering period of D. inoxia (July to

105 September), this locality has an average temperature of $18.8^{\circ} \mathrm{C}$, with a daily range from $7.4{ }^{\circ} \mathrm{C}$ to

$10630.8^{\circ} \mathrm{C}$, and a three-month total precipitation of $314 \mathrm{~mm}$. The Mapimí population (Map) is

107 located at $1157 \mathrm{~m}$ a.s.1. in the Mexican Plateau in the States of Coahuila and Durango $\left(26^{\circ} 41^{\prime}\right.$

$\left.10811^{\prime \prime} \mathrm{N} ; 103^{\circ} 44^{\prime} 49^{\prime} \mathrm{W}\right)$. This is a more xeric environment, with a quarterly average temperature

109 of $22.8^{\circ} \mathrm{C}$ (range: $12.6^{\circ} \mathrm{C}$ to $32.9^{\circ} \mathrm{C}$ ) and a total three-month precipitation of $253 \mathrm{~mm}$

110 (Meteorological Service of Mexico: http://smn.cna.gob.mx/). Collection of seed material for

111 experimental analyses was made under the permission SGPA-DGGFS-712-1596-17

112 (Subsecretaría de Gestión para la Protección Ambiental, Secretaría de Medio ambiente y

113 Recursos Naturales, Mexico).

114 Variation in the level of herkogamy within and among populations

115 Thirty reproductive plants were randomly selected and tagged for sampling in a 1 ha area within

116 each population. For each individual plant, 4 - 6 open flowers were randomly selected to measure

117 herkogamy. Herkogamy was calculated as the difference between pistil and stamen length.

118 Approach herkogamy was defined as the pistil surpassing the stamens in length (henceforth

119 "positive herkogamy"), whereas reverse herkogamy was the opposite trend (henceforth "negative 120 herkogamy”). Absence of herkogamy occurred when pistil and stamens had equal lengths. 
122 To estimate mating system parameters from each marked plant in the field, five mature fruits

123 derived from natural pollination were collected, labelled and bagged. In the laboratory, seeds of

124 each fruit were separated and germinated in a greenhouse, and seeds of each fruit within each

125 family (maternal plant) were sown in separate pots. Germination per fruit per family was

126 recorded for 30 days. To obtain an average estimate of germination rate per fruit, we recorded the

127 final number of seeds germinated in each pot. Germination percentage was $\geq 90 \%(\mathrm{se}=3.18)$ for

128 all plants. Once seedlings emerged, we collected leaf tissue from young plants, bagged, labelled,

129 and stored in an ultra-freezer at $-97^{\circ} \mathrm{C}$. Finally, we analyzed mating system parameters in 20

130 seedlings from each of 30 maternal families per population $(\mathrm{N}=600)$.

131 DNA was extracted from seedlings following the Miniprep protocol (Doyle \& Doyle,

132 1987). Five microsatellite nuclear loci developed for D. stramonium (Andraca, 2009) were

133 amplified for each seedling. Further, we standardized one additional microsatellite locus for $D$.

134 inoxia (F8: Rw: 5' -GGACAACATCTTTGCGACCC- 3'), in order to obtain a total of six

135 polymorphic microsatellite loci per individual plant. Primers were labelled with PET, VIC, 6-

136 FAM, and NED dyes (Applied Biosystems) (see Supplemental Information: PCR protocols).

137 Multilocus outcrossing $\left(t_{m}\right)$ and selfing $\left(s=1-t_{m}\right)$ rates, primary selfing rate $(r)$ and

138 inbreeding coefficient $(F)$ were estimated for each maternal family for each population. Mating

139 system parameters ( $t_{m}$ and $s$ ) at the family level were estimated with MLTR 3.2 (Ritland, 2002)

140 using the Expectation-Maximization method (EM), which allows missing data and undetected

141 null alleles (Ritland \& Jain, 1981). Standard errors and standard deviations were estimated by

142 bootstrapping, with 1000 replicates and re-sampling individuals at the family level. The

143 frequency of null alleles per locus, per population, was assessed using Micro-Checker v.2.2.3

144 (Cock et al., 2004). One locus (G8) did not amplify for any of the plants from CM, so analyses

145 were carried out with five loci in that population, and six loci in Map. Selfing rates ( $s$ ) obtained

146 from molecular markers, after fertilization and germination, might not be completely independent 
147 from inbreeding depression and thus may underestimate its true value (Lande, Schemske \&

148 Schultz, 1994). Primary selfing rate $(r)$ is a better predictor of mating system because it assesses

149 separately the magnitude of inbreeding depression. Hence, $r$ refers to the proportion of selfed

150 progeny at the time of fertilization (Lande, Schemske \& Schultz, 1994). The primary selfing rate

151 ( $r$ ) was calculated for each maternal family as: $r=s /[1-\delta+s \delta]$, where $s$ is the selfing rate

152 obtained from microsatellite loci, and $\delta$ is the cumulative inbreeding depression obtained for each

153 population (see below).

154 The inbreeding coefficient $(F)$ may include components of inbreeding other than just self-

155 or cross- fertilization, such as biparental inbreeding or population substructure. Here, we used $F$

156 as a proxy of the inbreeding history of each maternal family (i.e., adult cohort) (Latta \& Ritland,

157 1994). Inbreeding coefficient $(F)$ values were inferred for each lineage from the microsatellite

158 loci amplified previously, with GenePop v.4.2 (Rousset \& Raymond, 1995; Rousset, 2008). To

159 investigate whether inbreeding depression was associated with the selfing rate and herkogamy,

160 we calculated inbreeding coefficients at equilibrium $\left(F_{e}\right)$ (i.e., progeny cohort) for each lineage,

161 assuming that adult $F$ and $t_{m}$ are constant among generations (Ritland, 1990). We then related

162 these differences with selfing rate and herkogamy. Since $F_{e}$ increases in relation to $F$ due to self-

163 fertilization, larger differences between $F$ and $F_{e}$ at each maternal lineage should indicate the

164 presence of higher inbreeding depression. Once selection against inbred progeny has occurred, $F_{e}$

165 and $F$ will be equal (Ritland, 1990; Shirk \& Hamrick 2014). This approach yields an estimation

166 of potentially late-acting inbreeding depression in each lineage. $F_{e}$ was calculated as $F_{e}=\left(1-t_{m}\right) /$

$167\left(1+t_{m}\right)$, where $t_{m}$ is the outcrossing rate calculated from MLTR for each maternal family (Allard,

168 Jain \& Workman. 1968; Ritland, 1990).

169

170 Inbreeding depression 
172 plants in each population. These plants did not include the maternal families previously analyzed.

173 From each fruit, we sowed ten seeds on separate pots under greenhouse conditions. Average ( \pm

174 S.E.) environmental variables in the greenhouse (March-September), measured by HOBO sensors

175 (Onset Computer Corporation, USA) were: temperature $27.10 \pm 0.06{ }^{\circ} \mathrm{C}$; relative humidity 42.93

$176 \pm 0.09 \%$ and light intensity 3,133.59 \pm 18.73 Lux (Camargo, 2009). When seeds germinated, one

177 seedling per fruit was randomly chosen and grown under controlled conditions until flowering.

178 For each population, 100 individuals were randomly chosen to act as pollen receptors (mothers)

179 and 50 individuals as pollen donors (fathers). Two manual pollination treatments were applied to

180 each maternal plant: (1) cross-pollination $(o)$, where two flowers were emasculated before

181 anthesis and hand-pollinated with pollen from one donor randomly chosen from the same

182 population; (2) self-pollination treatment $(s)$, where two flowers of each receptor plant were

183 fertilized with self-pollen. After pollination, flowers in both treatments were bagged individually

184 with a fine nylon mesh. Since many mother plants did not produce the four flowers needed for

185 pollination treatment application, the final sample included mother plants that produced at least

186 one fruit per treatment (CM: $N=77$; Map: $N=41)$. Two fitness components per pollination

187 treatment were evaluated in each population: seed-set mean (i.e., number of seeds/ number of

188 ovules) and seed mass. Seed mass was obtained from a random sample of 30 seeds per fruit using

189 an analytical balance (Adventurer OHAUS). Allocating more resources to seeds can increase

190 quality of seeds, increasing the likelihood of successful seedlings' establishment and mothers'

191 fitness (Stanton \& Young, 1994; Byers \& Waller, 1999). In D. inoxia, as in D. stramonium, under

192 greenhouse experiments conditions, inbreeding depression on seed mass has been detected even

193 when maternal plants have been fertilized with a single pollen donor (Sosensky, 2004; Jiménez-

194 Lobato, 2013). Likely seed mass may influence germination rate and seedling establishment in

195 Datura species. 
$197 \delta=1-\frac{\dot{w}_{s}}{\dot{w}_{o}}$, where $\dot{w}_{s}$ and $\dot{w}_{o}$ are the mean fitness of progenies derived from self- or cross-

198 pollination, respectively. Average fitness of self- and out-cross progenies was calculated as the 199 product of seed-set and seed mass (Schemske \& Lande, 1985), and it was used to estimate the 200 primary selfing rate $(r)$ at each maternal lineage. This approach yields an estimate of early-acting 201 inbreeding depression

\section{Statistical analyses}

203 Statistical analyses were implemented in R software version 4.0.2 (R Development Core Team 204 2020). To estimate phenotypic variation in herkogamy within each population, we quantified the 205 variance components within and between individuals. Using the nlme package (Pinheiro et al., 206 2017), we fitted a linear mixed model for each population where maternal family and plants 207 nested within families were considered as random factors.

Statistical differences in primary selfing rates $(r)$, inbreeding in adult cohort $(F)$, inbreeding at equilibrium $\left(F_{e}\right)$ and an estimate of inbreeding depression $\left(F_{e}-F\right)$ between populations were tested by Analysis of Covariance (ANCOVA) in multcomp package (Hothorn,

211 Bretz \& Westfall, 2008). Population was considered as fixed factor and herkogamy as the 212 quantitative variable. correlated $(\mathrm{CM}$ : estimate $=-1.00, p=0.000$, d.f. $=25$; Map: estimate $=-0.969, p=0.000$, d.f. $=$ 27 ), hence we present here only the analyses for primary selfing rates $(r)$. Since $r$ is a proportion,

216 its relationship with herkogamy was analyzed with a beta regression using the betareg package

217 (Cribari-Neto \& Zeiles, 2010; Douma \& Weedon, 2018). This regression has been proposed for 
218 modeling continuous data limited to a specific interval $(0,1)$ (Ferrari \& Cribari-Neto, 2004). We

219 tested for cloglog, logit and log link functions and based on Akaike's criterion we selected the 220 model that best fit to the data. Estimates of $\beta$ and $\varnothing$ were obtained by maximum likelihood 221 estimation. $F, F_{e}$ and their differences were associated to herkogamy with a generalized linear 222 model with Gaussian error distribution (Crawley, 2013). It must be noted that $F_{e}$ is a theoretical 223 prediction based on the selfing rate $(r)$, and these quantities are therefore correlated by 224 construction. Likewise, their correlation with other variables would be very similar. Thus, to 225 avoid redundancy, we present the correlations of selfing rate with other variables.

\section{Results}

Variation in herkogamy and mating system parameters within and among populations

At CM plants were, on average, non-herkogamous (mean $=-4.72 ; \mathrm{sd}=5.5 \mathrm{~mm}$; range $=17.48$ $\mathrm{mm}$, from -13.83 to $+3.65 \mathrm{~mm})$. In this population 20 out of 27 individual plants $(74 \%)$ had reverse or no herkogamy and 7 (26\%) exhibited approach herkogamy (Fig. 1A). Herkogamy varied proportionally more among plants at Map than at $\mathrm{CM}(\mathrm{N}=29)$ but the average was positive $($ Mean $=2.57 \mathrm{~mm}$; $\mathrm{sd}=11.15 \mathrm{~mm}$; range $=44.8 \mathrm{~mm}$, from -20 to $+24.8 \mathrm{~mm})($ Fig. $1 \mathrm{~B})$. $(77.32 \%)$ than in $\mathrm{CM}(50.62 \%)$, indicating higher intra-individual variation in the latter population (Map: 22.68\%; CM: 49.38\%).

ANCOVAs indicate that primary selfing rates $(r)$, inbreeding at equilibrium $\left(F_{e}\right)$ and inbreeding depression $\left(F_{e}-F\right)$ (Table S1) differed between populations and are affected by herkogamy. Inbreeding in adult cohort $(F)$ was not different between populations and was unaffected by herkogamy (Table S1). 
241

242 The multilocus outcrossing rate $\left(t_{m}\right)$ was, on average, higher in Map than in CM (0.682 vs. 0.294)

243 although high variation in this parameter was detected among lineages in each population (Map,

2440.022 to 1 ; CM, 0 to 1 ). The distribution of $t_{m}$ is skewed toward low values in CM (ca. $60 \%$ of

245 mother plants), but towards high values in Map (50\% of the families with $\left.t_{m}>0.8\right)$ (Fig. 2A and

246 2B, respectively). Primary selfing rate (r) was two-fold higher in CM than in Map (0.716 vs.

2470.353 ), varying from $r=0$ to 1 and from $r=0$ to 0.978 , respectively.

248

249

Inbreeding coefficient in the adult cohort $(F)$ was negative in the two populations and

highly variable (CM: $F=-0.193$, range -1 to 0.75 ; Map: $F=-0.085$, range -0.553 to 1$)$.

Inbreeding coefficient at equilibrium $\left(F_{e}\right)$ was higher in $\mathrm{CM}$ than Map $\left(F_{e}=0.626\right.$ vs. 0.238$)$ and

highly variable in both populations (from 0 to 1 ). The difference between the $F$ of the adult cohort and the $F_{e}$ of the progeny cohort was much higher in CM than in Map $\left(F_{e}-F=0.819\right.$ vs. 0.323). The estimated magnitude of cumulative inbreeding depression, measured on greenhouse conditions, was higher in Map than in $\mathrm{CM}(\delta=0.25$ vs. $\delta=0.09)$.

\section{Relationships between herkogamy and mating system parameters}

Correlations between primary selfing rate $(r)$, inbreeding coefficient $(F)$, inbreeding coefficient at equilibrium $\left(F_{e}\right)$ and herkogamy were only significant in the Map population (Table 1, Figs. 3 and 4). Primary selfing rate $(r)$ (and hence $F_{e}$ ) were negatively associated with herkogamy only in Map population (Table 1; Figs. 3A and 3B), indicating that individuals with reverse herkogamy or without herkogamy had progenies with higher selfing rate and inbreeding coefficient than plants with approach herkogamy. The best beta regression model between $r$ and herkogamy was fitted with the log link function according to the Akaike's criterion (Table S2). In addition, the breeding history of each maternal lineage $(F)$ was associated with selfing $(r)$ in the Map population only (Figs. 4A and 4B), but not with herkogamy in either of the two populations ( $F$ 
265 vs. herkogamy) (Table 1; Figs. 3C and 3D). The $F_{e}-F$ difference was positively correlated with

266 primary selfing rate $(r)$ only in CM (Table 1; Figs. 4C and 4D). We did not find any indication of

267 a significant correlation between $F_{e}-F$ and herkogamy (Table 1; Figs. 3E and 3F). As expected,

268 progenies' inbreeding coefficient $\left(F_{e}\right)$ was positively correlated with primary selfing rates $(r)$ in

269 both populations (results not shown).

\section{Discussion}

272 In annual, short-lived, plant species, the evolution of plant mating system in association with

273 flower traits, such as herkogamy, depends on the constancy of natural selection within

274 populations according to the opportunity for cross- and self-fertilization every year (Shirk \&

275 Hamrick 2014). Because herkogamy is a direct modifier of the efficiency of self- and cross-

276 pollination, it is likely to coevolve with the plants' mating system, and the different within-

277 population lineages would be expected to vary in their history of inbreeding. Here, we evaluated

278 the association of herkogamy, mating system and inbreeding history at a lineage level within two

279 populations of Datura inoxia, an annual/short lived species distributed in arid and semiarid

280 environments in Mexico and southern USA.

We found that herkogamy, selfing rates and inbreeding coefficients, as well as

associations among them, varied considerably between and within populations. In line with

higher average outcrossing rate and lower inbreeding coefficient of progenies than individual plants that exhibited absence of and/or reverse herkogamy. These results are in line with the 
288 selfing/outcrossing rate and herkogamy has been found in other species of Datura such as $D$.

289 stramonium (Motten \& Antonovics, 1992; Motten \& Stone, 2000) and D. wrightii (Elle \& Hare, 290 2002) as well as in other species like Gilia achilleifolia (Takebayashi \& Morrell, 2001), Clarkia

291 temblorensis (Holtsford \& Ellstrand, 2006), Mimulus ringens (Karron et al., 1997), Nicotiana

292 glauca (Shueller, 2004), Aquilegia canadensis (Herlihy \& Eckert, 2007), Gesneria citrina (Chen

293 et al., 2009) and Dalechampia scandens (Opedal et al., 2016).

In the adult cohort of $D$. inoxia, we did not detect a significant association between the

inbreeding coefficient and herkogamy. This result suggests that the inbreeding history of each

296 lineage does not depend on herkogamy alone, and that purging of more inbred individuals and/or

297 biparental inbreeding may also come into play (Charlesworth \& Charlesworth, 1987). Reports of 298 low survival rate of inbred individuals at early life, i.e., high inbreeding depression, suggests 299 reductions of genetic load in adult plants (Medrano, Herrera \& Barret, 2005; Abdelaziz et al., 300 2014). In fact, in partially selfing populations it has been observed that $F$ in progeny cohorts 301 increase in relation to $F$ of the parental population, and later decrease again in the adult stage 302 (Ritland 1990; Eguiarte et al., 1993). If the purge of inbred individuals occurs at Mapimí, the 303 relationship between selfing rate in relation to flower herkogamy would be related to the on herkogamy (Medrano, Herrera \& Barret, 2005).

Although we do not know the causes of the relationship between herkogamy and mating system found in this study, fluctuation of environmental factors, especially pollinator abundance,

308 as it happens at Mapimí, can contribute to the maintenance of variation in herkogamy within 309 populations. Variation in herkogamy is linked with plants' reproductive assurance when 310 pollinators are scarce, or with high outcrossing rates when abundant (Kalisz, Vogler \& Hanley, 311 2004; Goodwillie, Kalisz \& Eckert, 2005; Chen et al., 2009). Since outcrossing rates in Mapimí 
312 are related to herkogamy, episodes of differential (or even contrasting) selection on herkogamy

313 among lineages over time may have favored either outcrossing (approach herkogamy) or selfing

314 (no herkogamy and/or reverse herkogamy). Further, phenotypic/genetic variance in herkogamy

315 could facilitate the maintenance of the mixed mating system of $D$. inoxia in Mapimí. The among

316 individual plants variance component in herkogamy strongly suggests genetic differences

317 between plants, beyond within-individual variance (i.e. heritability $>0$ ). In this sense, our results

318 may provide evidence the herkogamy is a functional trait linked to the reliability of pollinator

319 service in the different populations (Moeller, 2006; Opedal, 2018).

On the other hand, the mating system of the population of Cañada de Moreno is

321 predominantly selfing, and no association between selfing rates, herkogamy and inbreeding coefficients in the adult cohort were detected at this locality. Nevertheless, like the Mapimí population, there is a positive relationship between selfing rate and the $F_{e}-F$ difference. These results suggest inbreeding depression in selfing individuals followed by genetic purging (Ritland, 1990). The latter explanation is supported by the contrasting average values of inbreeding depression found in the two populations of D. inoxia, being lower in CM than in Map.

Theoretical models and experimental results have demonstrated that mutations that cause strong inbreeding depression can be purged from one generation to the next (Willis, 1999; Charlesworth \& Willis, 2009), but mutations that cause mild inbreeding depression and are rare can be maintained in populations for multiple generations (Lande, Schemske \& Schultz, 1994; Charlesworth \& Willis 2009). The expression of mutations with mild deleterious effects among inbred individuals of $D$. inoxia can help to explain the differences in inbreeding coefficients

333 between progeny and adult generations and its relationship with selfing rate. 
336 Armbruster \& Reed, 2005; Cheptou \& Donohue, 2011; Fox \& Reed, 2011). Both inbred and

337 outcross individuals may perform better under benign environments, and inbreeding depression 338 expresses only as limit and/stressful conditions (Angeloni, Ouborg \& Leimu, 2011). Further, it

339 has been predicted that selection against deleterious mutations occurs mainly during the early life 340 history stages and lowers towards later life cycle stages (Angeloni, Ouborg \& Leimu, 2011). In

341 this study the assessment of early inbreeding depression under greenhouse conditions could have

342 underestimated the magnitude it can reach in natural, stressful conditions, inhabited by Datura

343 inoxia. Yet, since we did detect early-acting inbreeding depression, results seem to be in

344 agreement with expected trends: CM population, a predominantly selfing population, expresses

345 low value of inbreeding depression than Map, possibly due to a faster purge of deleterious alleles.

346 Phenotypic variance in herkogamy results from genetic, developmental and environmental

347 factors (Herlihy \& Eckert, 2007; Vallejo-Marín \& Barrett, 2009; Camargo et al., 2017). However,

348 the evolution of mating system, linked to floral traits like herkogamy, requires additive genetic

349 variance. Additive genetic variance of corolla length and herkogamy has been detected in

350 populations of the annual Datura stramonium (Motten \& Stone, 2000; Juárez-Ramírez, 2008;

351 Camargo et al., 2017). Further, a quantitative survey of evolvability of herkogamy measured as

352 mean-scaled additive variance, points out the high evolutionary potential of herkogamy compared

353 to male and female sexual organs or flower size (Opedal et al., 2017). Our results, derived from

354 the partition of phenotypic variance in herkogamy among individual plants and random variation

355 (within individual variation or residual term), indicate a large amount of proportional variance

356 between individuals in each population, but notably more so in Mapimí $(77.32 \%)$ than in Cañada

357 de Moreno (50.62\%). Thus, there is a strong indication that individual variation in average

358 herkogamy in D. inoxia in Mapimí is genetically based and potentially adaptive (see Jiménez-

359 Lobato \& Núñez-Farfán 2012). High within-individual variation could be adaptive if, on average, 
360 high intra-individual variation is linked to higher fitness (Herrera, 2009; Camargo et al., 2017).

361 Otherwise, high intra-individual variation can be maintained in environments that are highly

362 unpredictable in pollinator's service along time. In the Cañada de Moreno population, the high

363 within-plant variation in herkogamy could limit selection on it, constraining an adaptive response

364 in this population (Falconer \& MacKay, 1996; Lynch \& Walsh, 1998).

365 Within-individual variation in plant traits, particularly in flower characters, can be

366 developmental in origin or elicited in response to environmental variability (Herrera, 2009;

367 Camargo et al., 2017). The stability of development or homeostasis has been associated with

368 different levels of heterozygosity, so that heterozygous individuals better buffer environmental

369 variation (Lerner, 1954). However, there is not clear consensus on this hypothesis; some evidence

370 points to the potential effect of inbreeding, with the fixation of deleterious alleles and genetic

371 drift influencing individuals' level of developmental stability (Clarke, 1993). To what extent

372 inbreeding and deleterious mutations are responsible for intra-individual flower trait variation in

373 the CM population is not known yet, but evidence suggests some developmental variation in

374 flower size and herkogamy, as shown in one highly inbred population of D. stramonium, is linked

375 to environmental variation (Camargo et al., 2017)

376

377 Conclusions

378 Associations between herkogamy, mating system and inbreeding history at a lineage level are

379 expected to occur within populations of self-compatible, hermaphroditic plant species. In $D$.

380 inoxia, as in other species of Datura, approach herkogamy is associated with higher outcrossing

381 rates and low levels of inbreeding in progeny. The results of this study show that populations of

382 D. inoxia are diverging in mating system characteristics with important genetic implications.

\section{Acknowledgments}


384 We thank the members of the Laboratory of Ecological Genetics and Evolution for field

385 assistance, particularly to Armando López Velázquez. Thanks to Rosalinda Tapia López for lab

386 assistance and to Rafael Torres and Adriana Pérez for greenhouse work assistance. We are

387 indebted to Øystein H. Opedal, Samuel Carleial and one anonymous reviewer for the critical

388 review, and editing, that greatly improved this contribution. We are particularly grateful to Kiko

389 Herrera’s family in the Mapimí Biosphere Reserve and to Tito Galván and family in Cañada de

390 Moreno. This study is part of the Ph. D. thesis of V. Jiménez-Lobato.

\section{References}

Abdelaziz M, Muñoz-Pajares AJ, Berbel M, Perfectti F, Gómez JM. 2014. Association between inbreeding depression and floral traits in a generalist-pollinated plant. Journal of Evolutionary Biology 27:2495-2506. DOI: 10.1111/jeb.12492.

Andraca GG. 2009. Genética de poblaciones comparada entre Datura stramonium y su herbívoro especialista Lema trilineata. Unpubl. B. Sc. Biology Thesis. National Autonomous University of Mexico. Mexico.

Allard R, Jain S, Workman P. 1968. The genetics of inbreeding populations. Journal of Chemical Information and Modeling 110:1689-1699.

Angeloni F, Ouborg NJ, Leimu R. 2011. Meta-analysis on the association of population size and life history with inbreeding depression in plants. Biological Conservation 144:35-43. DOI: 10.1016/j.biocon.2010.08.016.

Armbruster P, Reed DH. 2005. Inbreeding depression in benign and stressful environments. Heredity 95:235-242. DOI: 10.1038/sj.hdy.6800721. 
406 Ashman TL, Majetic CJ. 2006. Genetic constraints on floral evolution: A review and evaluation 407 of patterns. Heredity 96:343-352. DOI: 10.1038/sj.hdy.6800815.

408 Baker H. 1955. Self-compatible and establishment after "long dinstance" dispersal. Evolution $4099: 347-349$.

410

411

412

Barclay SA. 1959. Studies in the genus Datura (Solanaceae). I. Taxonomy of Subgenus Datura. Harvard University, Cambridge MA, USA.

Barrett SCH. 2002. Sexual interference of the floral kind. Heredity 88: 154-159.

Barrett SCH. 2010. Understanding plant reproductive diversity. Philosophical Transactions of the Royal Society B: Biological Sciences 365:99-109. DOI: 10.1098/rstb.2009.0199.

Bronstein JL, Huxman T, Horvath B, Farabee M, Davidowitz G. 2009. Reproductive biology of Datura wrightii: the benefits of a herbivorous pollinator. Annals of Botany 103:1435-1443. DOI: $10.1093 / \mathrm{aob} / \mathrm{mcp} 053$.

Brunet J, Eckert CG. 1998. Effects of floral morphology and display on outcrossing in Blue Columbine, Aquilegia caerulea (Ranunculaceae). Functional Ecology 12:596-606. DOI: 10.1046/j.1365-2435.1998.00231.x.

Brys R, Jacquemyn H. 2012. Effects of human-mediated pollinator impoverishment on floral traits and mating patterns in a short-lived herb: An experimental approach. Functional Ecology 26:189-197. DOI: 10.1111/j.1365-2435.2011.01923.x.

Byers DL, Waller DM. 1999. Do plant populations purge their genetic load? effects of population size and mating history on inbreeding depression. Annual Review of Ecology and Systematics 30: 479-513. 
427 Camargo ID, 2009. Valor adaptativo de la plasticidad fenotípica de Datura stramonium en

428 respuesta a la variación de grano fino y grueso en la disponibilidad de agua. Unpubl. M. Sc.

429 Thesis, Biological Sciences, National Autonomous University of Mexico, Mexico.

430 Camargo ID, Nattero J, Careaga SA, Núñez-Farfán J. 2017. Flower-level developmental

431 plasticity to nutrient availability in Datura stramonium: Implications for the mating system.

432 Annals of Botany 120:603-615. DOI: 10.1093/aob/mcx093.

433 Cheptou PO, Donohue K. 2011. Environment-dependent inbreeding depression: Its ecological

434 and evolutionary significance. New Phytologist 189:395-407. DOI: 10.1111/j.1469-

$435 \quad$ 8137.2010.03541.x.

436 Carr DE, Fenster CB. 1994. Levels of genetic variation and covariation for Mimulus

437 (Scrophulariaceae) floral traits. Heredity 72:606-618.

438 Charlesworth D, Charlesworth B. 1979. The evolutionary genetics of sexual systems in flowering 439 plants. Proceedings of the Royal Society of London-Biological Sciences 205:513-530.

$440 \quad$ DOI: $10.1098 / \mathrm{rspb} .1979 .0082$.

441 Charlesworth D, Charlesworth B. 1987. Inbreeding Depression and its Evolutionary

442 Consequences. Annual Review of Ecology and Systematics 18:237-268. DOI:

$443 \quad$ 10.1146/annurev.es.18.110187.001321.

444 Charlesworth D, Willis JH. 2009. The genetics of inbreeding depression. Nature Reviews

445 Genetics 10:783-796. DOI: 10.1038/nrg2664.

446 Charlesworth D, Wright SI. 2001. Breeding systems and genome evolution. Current Opinion in 447 Genetis \& Development 11:685-690.

448 Chen XS, Martén-Rodríguez S, Li QJ, Fenster CB. 2009. Potential autonomous selfing in 
449 Gesneria citrina (Gesneriaceae), a specialized hummingbird pollinated species with variable 450 expression of herkogamy. Journal of Integrative Plant Biology 51:973-978. DOI:

$451 \quad$ 10.1111/j.1744-7909.2009.00867.x.

452 Clarke GM. 1993. The genetic basis of developmental stability. I. Relationships between 453 stability, heterozygosity and genomic coadaptation. Genetica 89:15-23. DOI:

$454 \quad 10.1007 / \mathrm{BF} 02424502$.

455 Cock O, Hutchinson WF, Willis D, Shipley P. 2004. Micro-Checker: Software for identifying 456 and correcting genotyping errors in microsatellite data. Molecular Ecology Notes 4:535$457 \quad 538$.

458 Crawly MJ. 2013. The R Book. London: Wiley. DOI: 10.1016/0025-5408(96)80018-3.

459 Cribari-Neto F, Zeileis A. 2010. Beta Regression in R. Journal of Statistical Software 34: 24.

460 Crnokrak P, Barrett SCH. 2002. Perspective: purging the genetic load: a review of the 461 experimental evidence. Evolution 56:2347-2358.

462 Crnokrak P, Roff DA. 1999. Inbreeding depression in the wild. Heredity 83:260-270. DOI:

$463 \quad 10.1038 /$ sj.hdy.6885530.

464 Douma JC, Weedon JT. 2019. Analysing continuous proportions in ecology and evolution: A 465 practical introduction to beta and Dirichlet regression. Methods in Ecology and Evolution 466 10:1412-1430. DOI: 10.1111/2041-210X.13234.

467 Doyle JJ, Doyle JL. 1987. A rapid DNA isolation procedure from small quantities of fresh leaf 468 tissues. Phytochemical Bulletin 19:11-15. 
471 Eckert CG, Kalisz S, Geber MA, Sargent R, Elle E, Cheptou P-O, Goodwillie C, Johnston MO, 472 Kelly JK, Moeller DA, Porcher E, Ree RH, Vallejo-Marín M, Winn AA. 2009. Plant mating $473 \quad$ systems in a changing world. Trends in Ecology and Evolution 25:35-43. DOI:

$474 \quad$ 10.1016/j.tree.2009.06.013

475 Eckert CG, Samis K, Dart S. 2006. Reproductive assurance and the evolution of of uniparental 476 reproduction in flowering plants. In: Harder LD, Barrett SCH eds. The ecology and 477 evolution of flowers. UK: Oxford University Press, 183-203.

478 Eguiarte LE, Búrquez A, Rodríguez J, Martínez-Ramos M, Sarukhan J, Piñero D. 1993. Direct 479 and indirect estimates of neighborhood and effective population size in a tropical palm, $480 \quad$ Astrocaryum mexicanum. Evolution 47:75-87.

481
Elle E, Hare D. 2002. Environmentally induced variation in floral traits affects the mating system in Datura wrightii. Functional Ecology 16:79-88. DOI: 10.1046/j.0269-8463.2001.00599.x.

Epperson BK, Clegg MT. 1987. First-pollination primacy and pollen selection in the morning glory, Ipomoea purpurea. Heredity 58:5-14.

Falconer D, MacKay TF. 1996. Introduction to quantitative genetics. Pearson.

Ferrari SLP, Cribari-Neto F. 2004. Beta regression for modeling rates and proportions. Journal of Applied Statistics 31:799-815.

Fisher RA. 1941. Average excess and average effect of a gene substitution. Annals of Eugenics banner 11:53-63. 
490 Fox CW, Reed DH. 2011. Inbreeding depression increases with environmental stress: An 491 experimental study and meta-analysis. Evolution 65:246-258. DOI: 10.1111/j.1558$492 \quad 5646.2010 .01108 . x$.

493 Foxe JP, Slotte T, Stahl EA, Neuffer B, Hurka H, Wright SI. 2009. Recent speciation associated 494 with the evolution of selfing in Capsella. Proceedings of the National Academy of Sciences 495 106:5241-5245. DOI: 10.1073/pnas.0807679106.

496 Friedman J, Rubin MJ. 2015. All in good time: Undestanding annual and perennial strategies in 497 plants. American Journal of Botany 102: 497-499. DOI: 10.3732/ajb.1500062.

498 Goodwillie C. 1999. Multiple origins of self-compatibility in Linanthus section Leptosiphon 499 (Polemoniaceae): Phylogenetic evidence from internal-transcribed-spacer sequence data. 500 Evolution 53:1387-1395. DOI: doi.org/10.1111/j.1558-5646.1999.tb05403.x.

501 Goodwillie C, Kalisz S, Eckert CG. 2005. The evolutionary enigma of mixed mating systems in 502 plants: Occurrence, theoretical explanations, and empirical evidence. Annual Review of 503 Ecology, Evolution, and Systematics 36:47-79. DOI:

Grant V. 1983. Behavior of hawkmoths on flowers of Datura meteloides. Botanical Gazette 10.1146/annurev.ecolsys.36.091704.175539.

Herlihy CR, Eckert CG. 2007. Evolutionary analysis of a key floral trait in Aquilegia canadensis 508 (Ranunculaceae): Genetic variation in herkogamy and its effect on the mating system. $509 \quad$ Evolution 61:1661-1674. DOI: 10.1111/j.1558-5646.2007.00137.x.

510 Herrera CM. 2009. Fitness consequences of subindividual variability in organ traits for plants. In: 511 Multiplicity in unity: Plant subindividual variation \& interactions with animals. The 
$512 \quad$ University of Chicago Press, 265-310.

513 Holtsford TP, Ellstrand NC. 2006. Genetic and environmental variation in floral traits affecting 514 outcrossing rate in Clarkia tembloriensis (Onagraceae). Evolution 46:216-225. DOI:

$515 \quad 10.2307 / 2409816$.

516 Hothorn T, Bretz F, Westfall P. 2008. Simultaneous inference in general parametric models.

517 Biometrical Journal, 50: 346-363.

518 Husband CB, Schemske DW. 1996. Evolution of the magnitude and timing of inbreeding. $519 \quad$ Evolution 50:54-70.

Jiménez-Lobato, V. 2013. Diferenciación adaptativa de rasgos florales en Datura inoxia Mill. (Solanaceae). Unpubl. Doctoral Diss., Instituto de Ecología AC, Xalapa, Mexico.

Jiménez-Lobato V, Núñez-Farfán J. 2012. Population differentiation in floral characters of Datura inoxia mill. Evolutionary Ecology Research 14:1015-1038.

Juárez-Ramírez JO. 2008. Diferenciación adaptativa del fenotipo floral de Datura stramonium: varianza genética del néctar. Unpubl. B. Sc. Thesis, Biology. National Autonomous University of Mexico. Mexico.

Kalisz S, Vogler DW, Hanley KM. 2004. Context-dependent autonomous self-fertilization yields reproductive assurance and mixed mating. Nature 430:884-887.

Karron JD, Jackson RT, Thumser NN, Schlicht SL. 1997. Outcrossing rates of individual Mimulus ringens genets are correlated with anther-stigma separation. Heredity 79:365-370. DOI: $10.1038 /$ sj.hdy.6882300. 

48:965-978.

Latta R, Ritland K. 1994. The relationship between inbreeding depression and prior inbreeding among populations of four Mimulus taxa. Evolution 48:806-817. DOI: 10.2307/2410488.

Lerner IM. 1954. Genetic Homeostasis. New York: Wiley.

Lloyd DG. 1992. Self- and Cross- fertilization in plants. II. The selection of selfertilization. International Journal of Plant Science 153:370-380.

Lloyd DG, Webb CJ. 1986. The avoidance of interference between the presentation of pollen and

Lockwood TE. 1973. Generic recognition of Brugmansia. Botanical Museum Leaflets:273-284.

Lynch M, Walsh B. 1998. Genetics and analysis of quantitative traits. Sinauer. stigmas in angiosperms I. Dichogamy. New Zealand Journal of Botany 24:135-162. DOI: 10.1080/0028825x.1986.10409725.

McCall AC, Richman S, Thomson E, Edgerton M, Jordan S, Bronstein JL. 2018. Do honeybees act as pollen thieves or pollinators od Datura wrightii?. Journal of Pollination Ecology 24:164-171. DOI: dx.doi.org/10.26786/1920-7603\%282018\%2917

548 Medrano M, Herrera CM, Barret SCH. 2005. Herkogamy and mating patterns in the self549 compatible daffodil Narcissus longispathus. Annals of Botany 95:1105-1111. the evolution of self-pollination. Ecology 87:1510-1522. pollination environments. Evolution 59:1143-1148. 
554 Morran LT, Parmenter MD, Phillips PC. 2009. Mutation load and rapid adaptation favour 555 outcrossing over self-fertilization. Nature 462:350-352. DOI: 10.1038/nature08496.

556 Motten AF, Antonovics J. 1992. Determinants of outcrossing rate in a predominantly self557 fertilizing weed, Datura stramonium (Solanaceae). American Journal of Botany 79:419558 427. DOI: $10.2307 / 2445154$.

559 Motten AF, Stone JC. 2000. Heritability of stigma position and the effect of stigma-anther 560 separation on outcrossing in a predominantly self-fertilizing weed, Datura stramonium 561 (Solanaceae). American Journal of Botany 87:339-347. DOI: 10.2307/2656629.

562 Opedal ØH. 2018. Herkogamy, a principal functional trait of plant reproductive biology. 563 International Journal of Plant Sciences 179:677-687. DOI: 10.1086/700314.

564 Opedal ØH, Armbruster WS, Pélabon C. 2015. Inbreeding effects in a mixed-mating vine: 565 Effects of mating history, pollen competition and stress on the cost of in breeding. $A o B$ $566 \quad$ PLANTS 7:1-13. DOI: 10.1093/aobpla/plv133.

567 Opedal ØH, Bolstad GH, Hansen TF, Armbruster WS, Pélabon C. 2017. The evolvability of 568 herkogamy: Quantifying the evolutionary potential of a composite trait. Evolution 71:1572569 1586. DOI: $10.1111 /$ evo.13258.

570 Opedal ØH, Albersten E, Armbruster WS, Pérez-Barrales R, Falahati-Anbaran M, Pélabon C.

571 2016. Evolutionary consequences of ecological factors: pollinator reliability predicts 572 mating-system traits of a perennial plant. Ecology Letters 19: 1486:1495.

574 Pannell JR. 2015. Evolution of the mating system in colonizing plants. Molecular Ecology 575 24:2018-2037. DOI: 10.1111/mec.13087. 
576 Pinheiro J, Bates D, Sarkar D, Team R. 2017. nlme: Linear and nonlinear mixed effects models.

$577 \quad$ R package.

578 R Development Core Team. 2020. R: A language and environment for statistical computing.

579 Ritland K. 1990. Inferences about inbreeding depression based on changes of the inbreeding $580 \quad$ coefficient. Evolution 44:1230-1241. DOI: 10.2307/2409284.

581 Ritland K. 2002. Extensions of models for the estimation of mating systems using $\mathrm{n}$ independent 582 loci. Heredity 88:221-228. DOI: $10.1038 / \mathrm{sj} / \mathrm{hdy} / 6800029$.

583 Ritland K, Jain S. 1981. A model for the estimation of outcrossing rate and gene frequencies $584 \quad$ using $\mathrm{n}$ independent loci. Heredity 47:35-52. DOI: 10.1038/hdy.1981.57.

585 Rousset F. 2008. GENEPOP'007: A complete re-implementation of the GENEPOP software for 586 Windows and Linux. Molecular Ecology Resources 8:103-106. DOI: 10.1111/j.1471$587 \quad$ 8286.2007.01931.x.

Rousset F, Raymond M. 1995. Testing heterozygote excess and deficiendy. Genetics 140:14131419. DOI: $10.1016 /$ j.jpeds.2008.07.054.

Schemske DW, Lande R. 1985. The evolution of self-fertilization and inbreeding depression in plants. II. Empirical observations. Evolution 39:41-52.

Schoen DJ, Lloyd DG. 1992. Self- and cross-fertilization in plants. III. Methods for studying modes and functional aspects of self-fertilization. International Journal of Plant Sciences 153:381-393. DOI: 10.1086/297042.

596 floral ecology and molecular genetic variation. Philosophical Transactions of the Royal 
598

599

600

601

602

603

604

605

606

607

608

609

610

611

612

613

614

615

616

Schueller SK. 2004. Self-pollination in island and mainland populations of the introduced hummingbird-pollinated plant, Nicotiana glauca (Solanaceae). American Journal of Botany 91:672-681.

Shirk RY, Hamrick JL. 2014. High but variable outcrossing rates in the invasive Geranium carolinianum (Geraniaceae). American Journal of Botany 101:1200-1206.

Sicard A, Lenhard M. 2011. The selfing syndrome: A model for studying the genetic and evolutionary basis of morphological adaptation in plants. Annals of Botany 107:1433-1443. DOI: $10.1093 / \mathrm{aob} / \mathrm{mcr} 023$.

Sosenski, P. 2004. Variación geográfica en el sistema de apareamiento en Datura stramonium. Unpubl. B. Sc. Thesis, Biology, National Autonomous University of Mexico. Mexico.

Stanton M, Young HJ. 1994. Selecting for floral character associations in wild radish Raphanus sativus L. Journal of Evolutionary Biology 7: 271-285.

Stebbins LG. 1957. Self fertilization and population variability in the higher plants. The American Naturalist XCI:337-354.

Takebayashi N, Delph LF. 2000. An association between a floral trait and inbreeding depression. Evolution 54:840-846. DOI: 10.1111/j.0014-3820.2000.tb00084.x.

Takebayashi N, Morrell PL. 2001. Is self-fertilization an evolutionary dead end? Revisiting an old hypothesis with genetic theories and a macroevolutionary approach. American Journal of Botany 88:1143-1150. DOI: 10.2307/3558325.

617 Takebayashi N, Wolf DE, Delph LF. 2006. Effect of variation in herkogamy on outcrossing 
618 within a population of Gilia achilleifolia. Heredity 96:159-165. DOI:

$619 \quad$ 10.1038/sj.hdy.6800780.

620 Toräng P, Vikström L, Wunder J, Wötzel S, Coupland G, Ågren J. 2017. Evolution of the selfing 621 syndrome: Anther orientation and herkogamy together determine reproductive assurance in 622 a self-compatible plant. Evolution 71:2206-2218. DOI: 10.1111/evo.13308.

623 Vallejo-Marín M, Barrett SCH. 2009. Modification of flower architecture during early stages in 624 the evolution of self-fertilization. Annals of Botany 103:951-962. DOI:

$625 \quad 10.1093 / \mathrm{aob} / \mathrm{mcp} 015$.

626 de Vos JM, Keller B, Zhang L-R, Nowak MD, Conti E. 2018. Mixed mating in homostylous 627 species: Genetic and experimental evidence from an alpine plant with variable herkogamy, 628 Primula halleri . International Journal of Plant Sciences 179:87-99. DOI: 10.1086/695527.

629 Webb CJ, Lloyd DG. 1986. The avoidance of interference between the presentation of pollen and 630 stigmas in angiosperms II. Herkogamy. New Zealand Journal of Botany 24:163-178. DOI: 631 10.1080/0028825X.1986.10409726.

632 Willis JH. 1999. The role of genes of large effect on inbreeding depression in Mimulus guttatus. 633 Evolution 53:1678-1691. DOI: doi.org/10.1111/j.1558-5646.1999.tb05403.x.

634 Wright SI, Kalisz S, Slotte T. 2013. Evolutionary consequences of self-fertilization in plants.

635 Proceedings of the Royal Society B: Biological Sciences 280. DOI: 10.1098/rspb.2013.0133.

636 Yahara T. 1992. Graphical analysis of mating system evolution in plants. Evolution 46:557-561. 


\section{Figure 1}

Figure 1

Herkogamy value average of individual plants of Datura inoxia. A. Cañada de Moreno and B. Mapimí. Error bars indicate 1 standard deviation. 


\section{A. Cañada de Moreno}

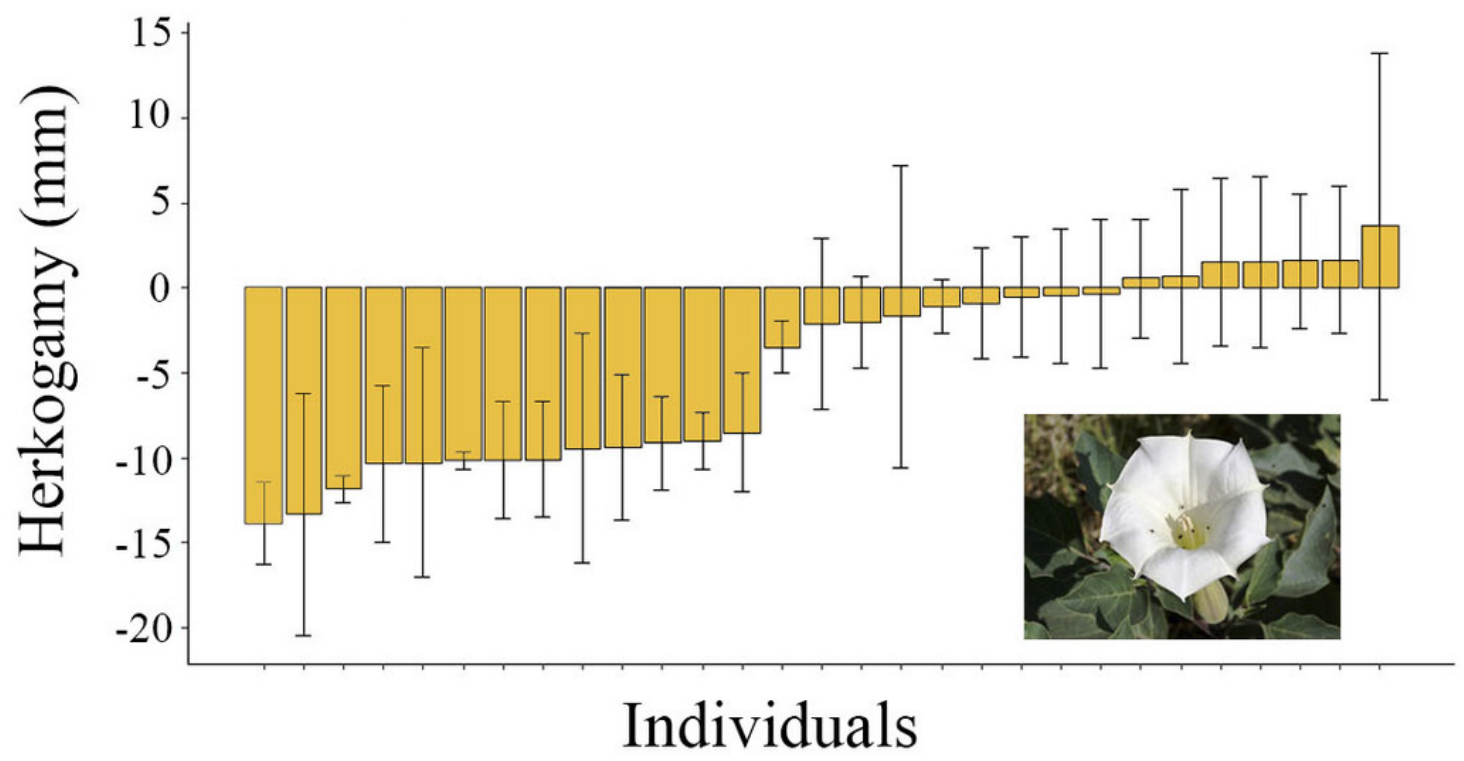

\section{B. Mapimí}

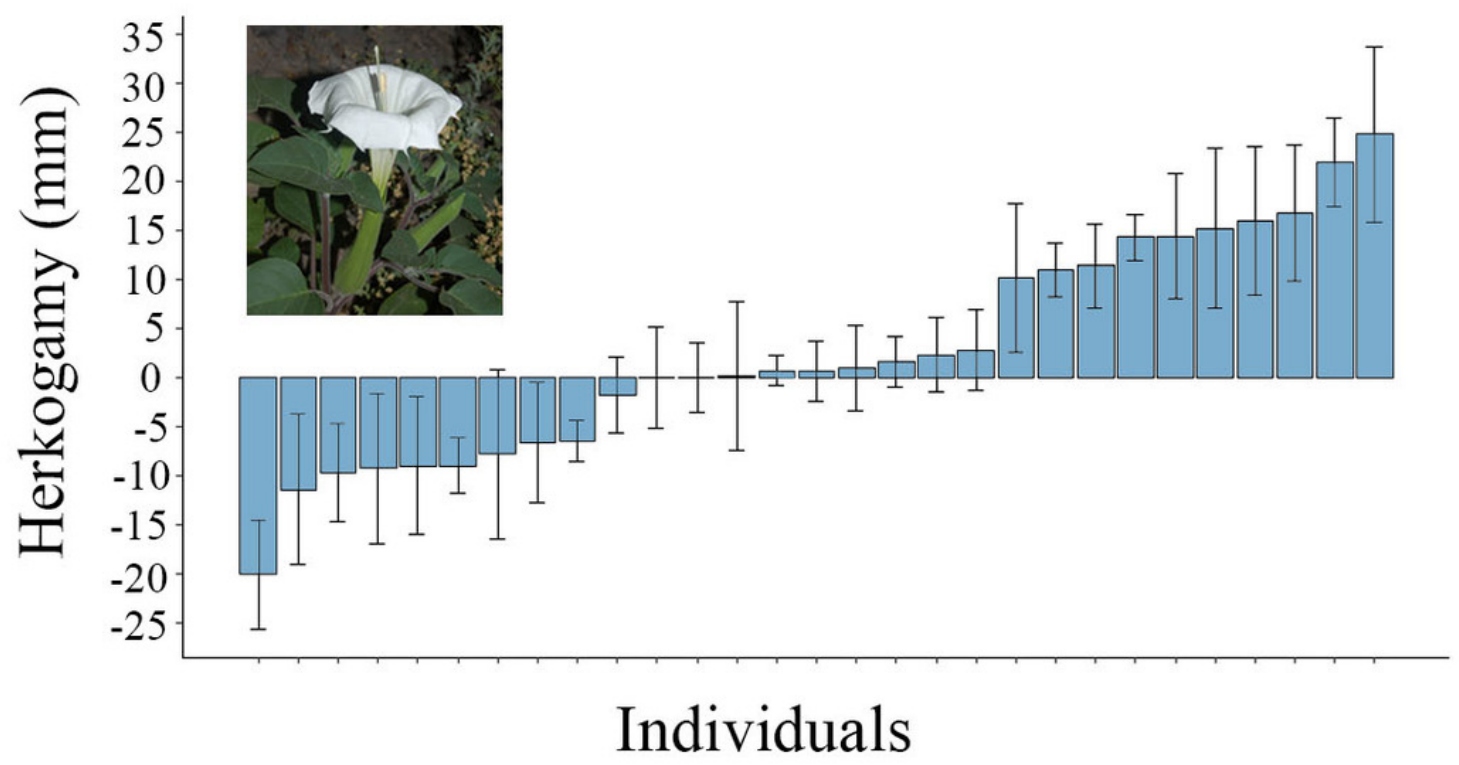


Figure 2

Figure 2

Histogram and boxplot graphs of outcrossing rate $(t)$ for two populations of Datura inoxia in Mexico: A. Cañada de Moreno and B. Mapimí. Boxplots show quartiles and the median value for each population.

A. Cañada de Moreno
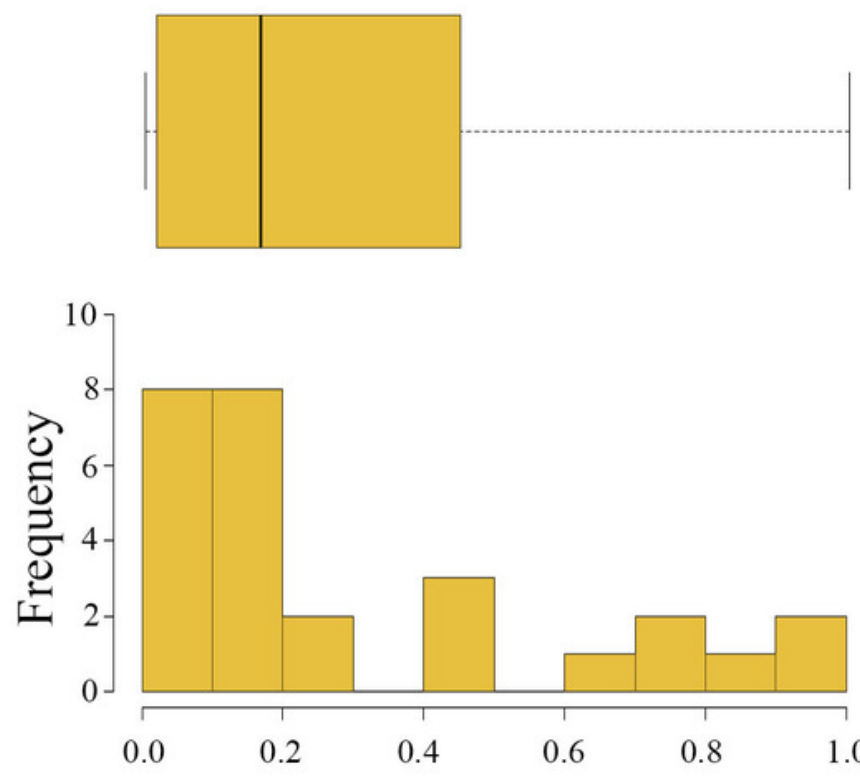

Outcrossing rate $\left(t_{m}\right)$
B. Mapimí
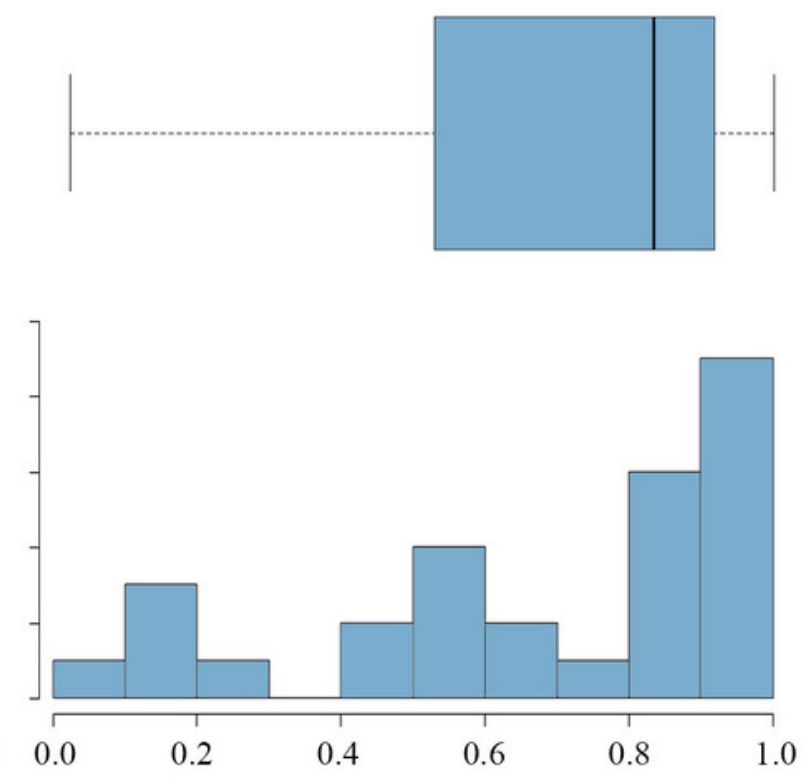

Outcrossing rate $\left(t_{m}\right)$ 


\section{Figure 3}

Figure 3

Relationships between primary selfing rates $(r)$, inbreeding coefficients estimated in adult cohort $(F)$, and inbreeding coefficients at equilibrium $(F e)$ (progeny cohort), with herkogamy values in two populations of Datura inoxia in Mexico. Fitted model is depicted only for the significant correlation (B). 
Cañada de Moreno

\section{Mapimí}

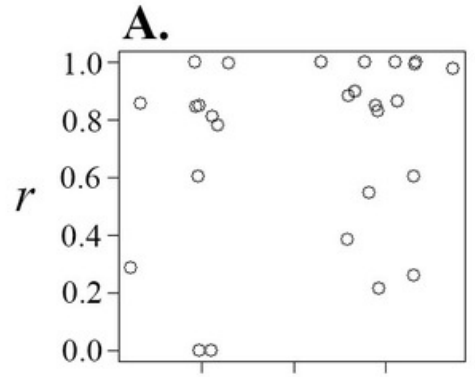

\section{B.}
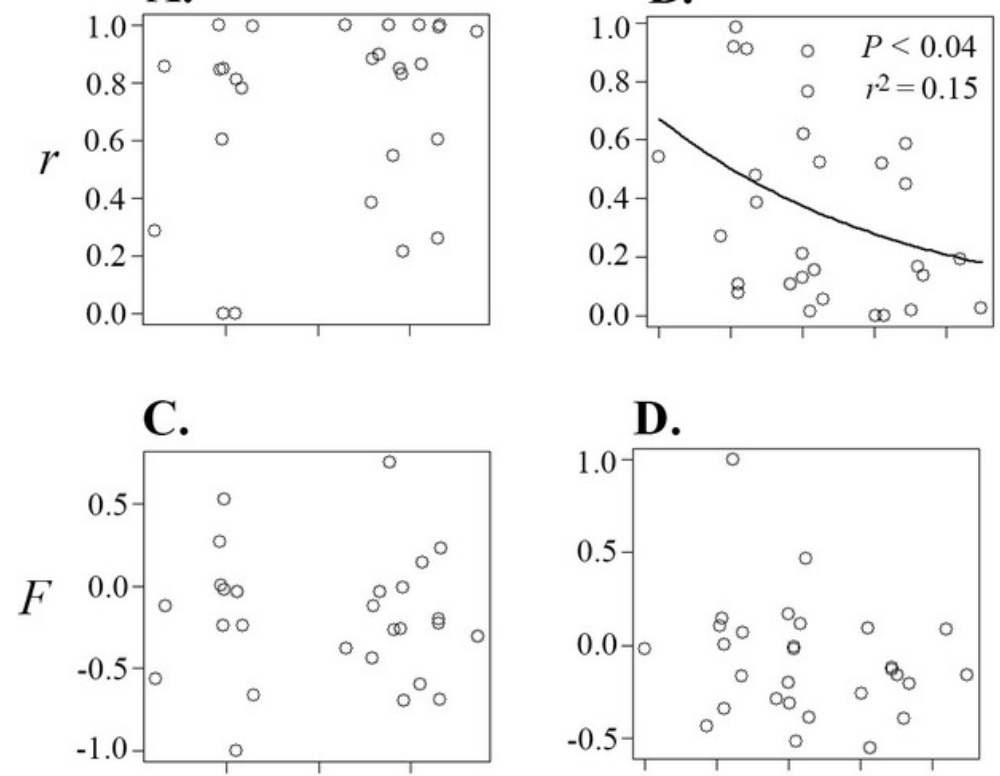

D.
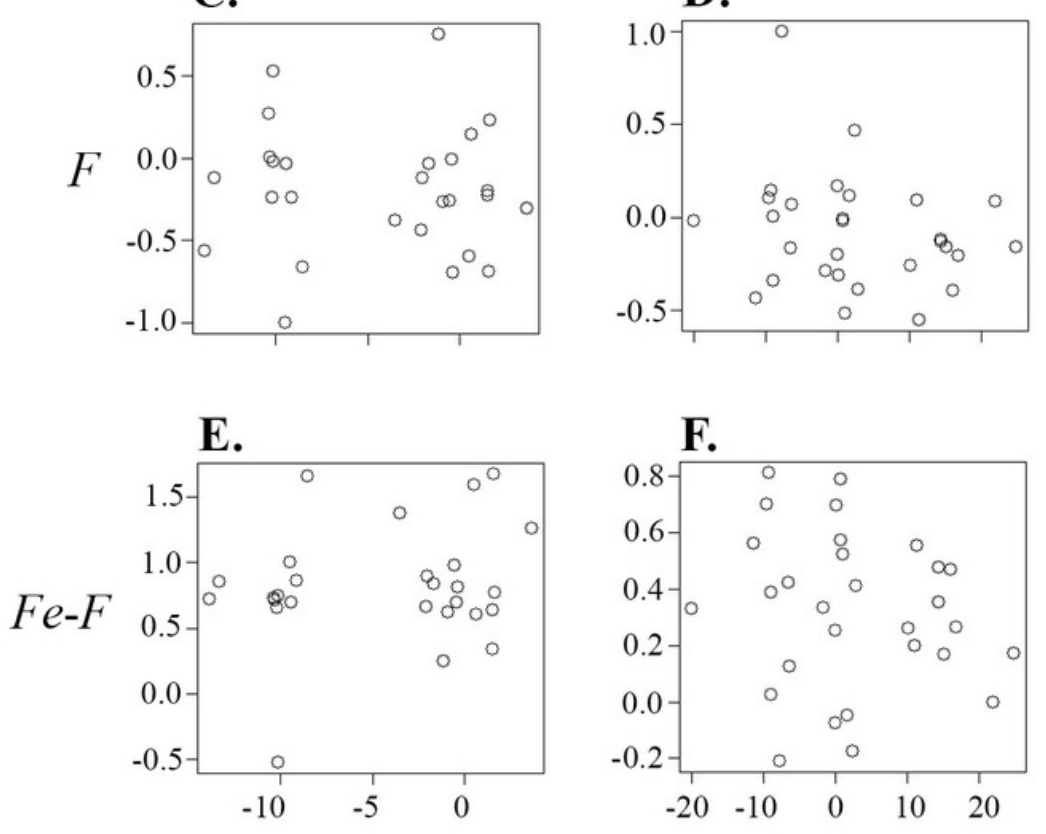

Herkogamy (mm)

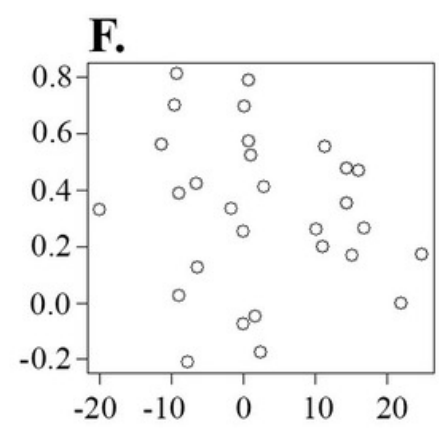

Herkogamy (mm) 


\section{Figure 4}

Figure 4

Correlation between inbreeding coefficient $(F)$, and the differences between inbreeding coefficients at equilibrium $(F e)$ and $F(F e-F)$, with primary selfing rates $(r)$ in two populations of Datura inoxia in Mexico. Fitted model is depicted only for the significant correlations (B and C). 
Cañada de Moreno
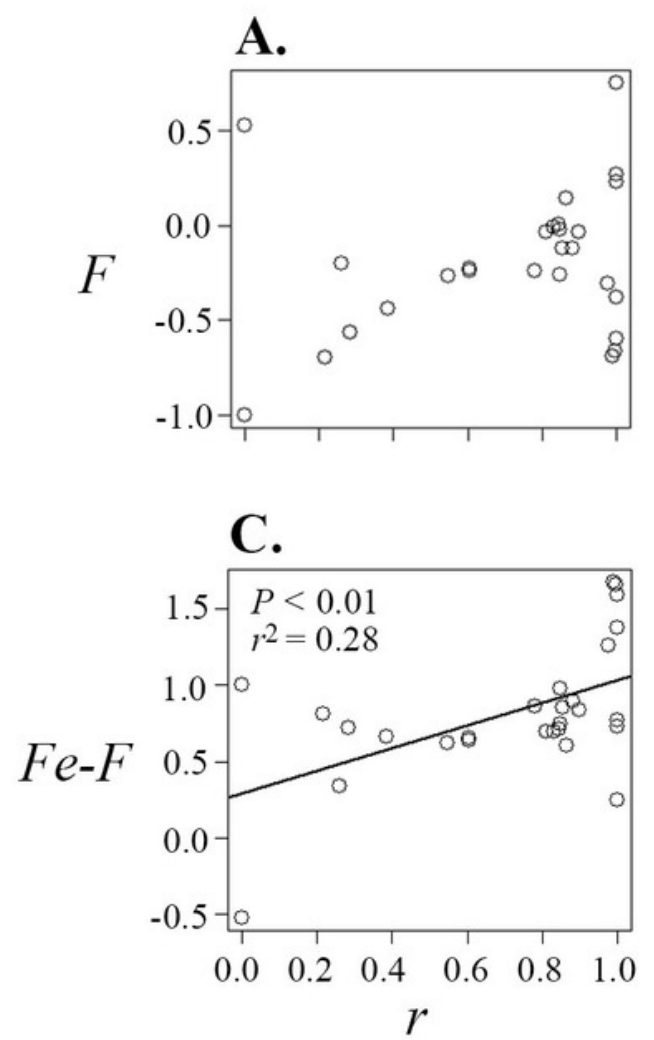

\section{Mapimí}
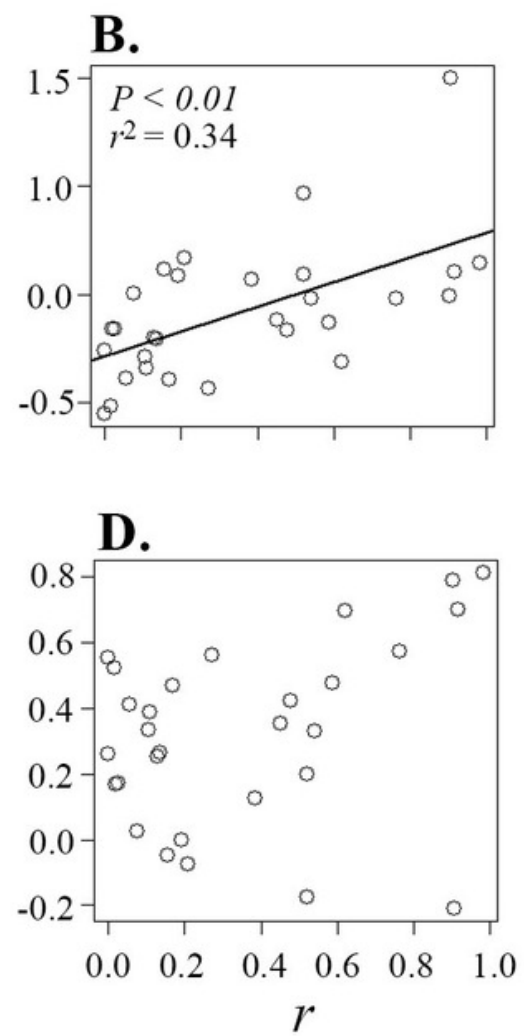


\section{Table $\mathbf{1}$ (on next page)}

Table 1

Correlation between primary selfing rate $(r)$, inbreeding coefficient (adult cohort: $F$ ), inbreeding coefficient at equilibrium (progeny cohort: $\mathrm{Fe}$ ), the difference between $\mathrm{Fe}$ and $\mathrm{F}$ ( $F e-F)$ and herkogamy in two populations of Datura inoxia(Cañada de Moreno, and Mapimí). Parameter estimates (above diagonal) and their standard error (below diagonal). Significant values are shown in bold type. Statistical models used in each test are described in the Materials and Methods section. 
Cañada de

Moreno

\begin{tabular}{l|ccccc} 
Moreno & $r$ & Herkogamy & $F$ & $F e$ & $F e-F$ \\
\hline$r$ & - & 0.023 & 0.307 & $\mathbf{0 . 9 8 2 * * *}$ & $\mathbf{0 . 7 3 9 * *}$ \\
Herkogamy & 0.016 & - & -0.001 & 0.014 & 0.015 \\
$F$ & 0.234 & 0.014 & - & na & na \\
$F e$ & 0.044 & 0.012 & na & - & na \\
$F e-F$ & 0.239 & 0.016 & na & na & - \\
\hline
\end{tabular}

Mapimí

\begin{tabular}{l|ccccc}
\hline$r$ & - & $\mathbf{- 0 . 0 2 9 *}$ & $\mathbf{0 . 5 7 2} * *$ & $\mathbf{0 . 8 5 4} * * *$ & 0.283 \\
Herkogamy & 0.012 & - & -0.006 & $\mathbf{- 0 . 0 0 9 *}$ & -0.004 \\
$F$ & 0.154 & 0.005 & - & na & na \\
$F e$ & 0.042 & 0.004 & na & - & na \\
$F e-F$ & 0.158 & 0.005 & na & na & - \\
\hline$P<0.05, * * P \leq 0.005, * * * P<0.0005$ indicate significant association between variables.
\end{tabular}

